ORIGINAL RESEARCH PAPER

Presented at the $9^{\text {th }}$ International Symposium EuroAliment 2019

\title{
ASSESSMENT OF QUINOA FLOURS EFFECT ON WHEAT FLOUR DOUGH RHEOLOGY AND BREAD QUALITY
}

\author{
RADIANA-MARIA TAMBA-BEREHOIU*, MIRA O. TURTOI*, CIPRIAN N. POPA** \\ ${ }^{*}$ University of Agronomic Sciences and Veterinary Medicine of Bucharest, 59 Marasti Blvd, District 1, Bucharest, \\ Romania, Phone: +402131825 64/232, Fax: + 40213182888 , \\ radianatamba@yahoo.com; turtoi_m@yahoo.com; \\ ${ }^{* * *}$ Milling Bakery Research \& Consulting, 8B Diamantului street, Bragadiru town, Ilfov district, Romania, \\ Phone:+40 7272778 40, Fax: +40318156038 \\ Corresponding author: cipnpopa@yahoo.com
}

Received on $26^{\text {th }}$ August 2019

Revised on $26^{\text {th }}$ November 2019

\begin{abstract}
The aim of the research was to evaluate the effect of addition of white and red quinoa whole flours $(15 \%$ and $30 \%)$ on the physical-chemical and rheological parameters of white and dark wheat flours, in order to optimize the mixtures for bakery products. Flours were analysed in terms of moisture, protein and ashe content, wet gluten, gluten index, falling number, dough farinographic and alveographic parameters. In addition bread specific volume, porosity, crumb moisture and technological water absorption were determined. The optimum bakery potential of wheat flour mixtures with quinoa flours was decided based on the high extensibility and low resistance of dough. For additions up to $15 \%$ white quinoa flour, the breads had the highest specific volumes ( $3.8 \mathrm{ml} / \mathrm{g}$ dark flour; 2.5 $\mathrm{ml} / \mathrm{g}$ white flour).
\end{abstract}

Keywords: bread, quinoa flour, physico-chemical parameters, dough rheological parameters, wheat flour

\section{Introduction}

Quinoa (Chenopodium quinoa) is a South American pseudocereal, considered one of the solutions to the challenges of ensuring human food security in the context of climate change and demographic growth. The plant is characterized by a high ecological plasticity and a unique nutritional and phyto-pharmaceutical profile.

The efficacy coefficient of quinoa proteins is appreciated by the literature as being casein-like, and their digestibility can be increased by thermal treatments (Ranhotra

https://doi.org/10.35219/foodtechnology.2019.2.12 
et al., 1993; Chauhan et al., 1992; Ruales et al., 1992). A series of low molecular weight peptides, obtained from the enzymatic hydrolysis of quinoa proteins, have anti-hypertensive, anti-oxidative (Aluko and Monu, 2003) and cholesterol-lowering potential (Takao et al., 2005).

The carbohydrates composition is similar to other cereals (73.0-74.0\% D.M.), the major component being starch $(52-70 \%$ D.M.). The total dietary fibers content varies from author to author in the range of 7.0-10.0\% D.M. (Wright et al., 2002; Mundigler, 1998; Ranhotra et al., 1993). Quinoa polyglucides have hypoglycaemic effects and are involved in reducing the fatty acids level in blood (Berti et al., 2004). In vitro digestibility of whole starch from quinoa was reported to be $22 \%$ and may increase up to $73 \%$ depending on the applied type of thermal treatments (Ruales and Nair, 1992).

The amount of quinoa seeds lipids is estimated to be between 1.8-9.5\%. Relative to the D.M. quinoa seeds have an amount of lipids (7\%) superior to maize $(4.5 \%)$ and the quinoa fatty acids profile is similar to corn oil or soybean (Koziol, 1993). Linoleic acid (C18:2) is one of the most abundant polyunsaturated fatty acid identified in quinoa. It has positive effects regarding the protection of the cardiovascular system (Abeywardena et al., 1991). Also, in the lipid fraction of quinoa seeds there is a significant amount of tocopherols $(0.6-2.6 \mathrm{mg} / 100 \mathrm{~g})$ that prevents the oxidation of flour lipids and ensures their stability up to 30 days (Ryan et al., 2007; Su-Chuen et al., 2007). In the unsaponifiable lipid fraction, significant amounts of squalene (34.0-58.0 $\mathrm{mg} / 100 \mathrm{~g})$ and phytosterols ( $\beta$-sistosterol $63.7 \mathrm{mg} / 100 \mathrm{~g}$, campesterol $15.6 \mathrm{mg} / 100 \mathrm{~g}$ and stigmasterols $3.2 \mathrm{mg} / 100 \mathrm{~g}$ ) have been identified (Ryan et al., 2007; Park et al., 2005). These substances have an indirect (as precursors of bioactive compounds) or direct effect on maintaining the cardiovascular system health. At the same time their antitumoral, antioxidative, anti-inflammatory and blood cholesterol regulation effect was proven. The concentration of these bioactive compounds in quinoa seeds is higher than in the case of pumpkin, barley or corn seeds and supplements the recommended daily dietary quantities of phytosterols required for food (0.8-1 g/day) (Moreau et al., 2002; Ryan et al., 2007; Berger et al., 2004).

Quinoa is also an important source of vitamins, especially B vitamins. An amount of $100 \mathrm{~g}$ of quinoa seeds can supplement vitamin B6 and folic acid daily requirements, respectively $80 \%$ of daily riboflavin requirements for adults (Ranhotra et al., 1993).

The functional properties of quinoa flour, such as solubility, water binding, gelatinization, foaming or emulsifying properties, are described in a series of studies. It is appreciated that the solubility of quinoa flour proteins is increased when exposed to thermal treatments (baking), respectively at $\mathrm{pH} 6$ and maximum at pH 10 (Ogungbenle, 2003; Oshodi et al., 1999). The water retention capacity is estimated to be about $147 \%$, lowered by the presence of salt. The gelatinization capacity, defined as the "minimum amount of quinoa flour in a certain volume of distilled water necessary for the mixture to gelatinize", was evaluated at $16 \%$ (Ogungbenle, 2003; Ogungbenle et al., 2009). The foam formation capacity is 
considered poor, but the emulsifying capacity and the stability of the formed emulsions are considered good. Thus, a number of authors estimate this capacity as $46 \%$, expressed as an absorption capacity of the oil. These features highlight the excellent potential of using quinoa flour in technologies for making beverages, sauces, desserts, sausages etc. (James, 2009).

The quinoa whole flour is obtained by dry milling of quinoa seeds, after a prior removal of saponins from the pericarp (by rinsing in cold or alkaline water or mechanical abrasion). Quinoa milling technologies are oriented towards selection of seeds varieties, poorer in saponins (sweet taste varieties and less intense bitter flavor) (Jancurová et al., 2009). The presence of saponins in seeds pericarp is considered the main nutritional disadvantage of the plant, as they were extremely toxic, according to classical medical literature. However, more recent researches suggest that the saponins may be involved in lowering the plasma cholesterol level, or in the decrease of gallbladder salts concentration (Valencia-Chamorro, 2003).

The aim of the research was to evaluate the effect of two types of quinoa whole flours on the physical-chemical and rheological parameters of wheat flours, in order to optimize the usable amounts in the bakery products recipes.

\section{Materials and methods}

Two types of wheat flours and two types of quinoa flours were analyzed, as follows: dark wheat flour (M1), white wheat flour (M2), whole white quinoa flour (WQ) and whole red quinoa flour (RQ), obtained by dry milling of quinoa seeds, purchased from the Romanian market. Milling was performed on a Perten 1500 laboratory mill, to average particle sizes of less than $500 \mu$ (in table 3 one can see the flours mineral content).

The experimental plan included the testing of wheat flours, as well as their mixtures with $15 \%$ and $30 \%$ of quinoa flours, according to Table 1 . The tests were performed in three repetitions, taking into consideration the mean values $(\mathrm{n}=3)$.

Recipes and the methodology used to obtain finished products, respectively breads, are shown in Table 2.

\section{Statistical analysis}

Interpretation of results was performed using computer-assisted statistical analysis (descriptive statistics, $t$ test) Microsoft Excel programs have been used to run dispersion calculations. Significance tests were performed using Statistica software from StatSoft, Inc.

\section{Results and discussion}

\section{Characterization of the flours}

Table 3 presents the results of the physical-chemical analysis for the wheat flours and mixtures of wheat flours with white and red quinoa flours $(n=3)$. 
Table 1. Experimental variants and tested quality parameters

\begin{tabular}{|c|c|c|c|c|c|}
\hline Variant & $\begin{array}{l}\text { Wheat } \\
\text { dark } \\
\text { flour\% }\end{array}$ & $\begin{array}{l}\text { Wheat } \\
\text { white } \\
\text { flour\% }\end{array}$ & $\begin{array}{l}\text { WQ } \\
\text { flour } \\
(\%)\end{array}$ & $\begin{array}{l}\text { RQ } \\
\text { flour } \\
(\%)\end{array}$ & $\begin{array}{l}\text { Methods used for estimating quality } \\
\text { parameters }\end{array}$ \\
\hline $\begin{array}{c}\text { M1 } \\
\text { (control 1) }\end{array}$ & 100 & 0 & 0 & 0 & \multirow{5}{*}{$\begin{array}{l}\text { Wheat flours and mixtures with quinoa flours: } \\
\text { Moisture (M\%, } 130^{\circ} \text { C, thermobalance } \\
\text { Precisa XM 60), protein content P\% (NIR } \\
\text { method, Perten INFRAMATIC 8600), Ash } \\
\text { content (A\% SR ISO 2171:2007 at } 900^{\circ} \text { C), } \\
\text { wet gluten content WG\% and gluten index GI } \\
\text { (ICC no. 155 method), falling number FN } \\
\text { (ISO 3093); farinogram (ISO 5530-1:2013), } \\
\text { alveogram (ISO 27971:2015). }\end{array}$} \\
\hline M1-15WQ & 85 & 0 & 15 & 0 & \\
\hline M1-30WQ & 70 & 0 & 30 & 0 & \\
\hline M1-15RQ & 85 & 0 & 0 & 15 & \\
\hline M1-30RQ & 70 & 0 & 0 & 30 & \\
\hline $\begin{array}{c}\text { M2 } \\
\text { (control 2) }\end{array}$ & 0 & 100 & 0 & 0 & \multirow{2}{*}{$\begin{array}{l}\text { Quinoa flours: Moisture (M\%, } 130^{0} \mathrm{C} \text {, } \\
\text { thermobalance Precisa XM } 60) \text {, Ash content } \\
\left.\text { (A\%, SR ISO 2171:2007 at } 900^{\circ} \mathrm{C}\right) \text {, Protein } \\
\text { content (P\% SR ISO 1871:2002) }\end{array}$} \\
\hline M2-15WQ & 0 & 85 & 15 & 0 & \\
\hline M2-30WQ & 0 & 70 & 30 & 0 & \multirow{3}{*}{$\begin{array}{l}\text { Bread ( } 2 \text { hours after being removed from the } \\
\text { oven): Specific Volume, (V g/ml, gravimetric } \\
\text { method STAS 91/1983), Porosity (Po\%, } \text {, } \\
\text { STAS 91/1983) and Moisture (M\%, } 130^{\circ} \text {, } \\
\text { thermobalance Precisa XM 60) }\end{array}$} \\
\hline M2-15RQ & 0 & 85 & 0 & 15 & \\
\hline M2-30RQ & 0 & 70 & 0 & 30 & \\
\hline
\end{tabular}

Table 2. Recipes and technological process for baking tests

\begin{tabular}{|c|c|}
\hline Recipe & Technology \\
\hline $\begin{array}{l}2.5 \% \text { dry yeast Pakmaya } \\
\mathbf{1 . 5} \% \text { salt } \\
\text { water - variable, depending on farinographic } \\
\text { water absorption\% (WA), in order to obtain a } \\
\text { normal consistency of dough } \\
\mathbf{0 . 3} \% \text { baking conditioner - Pan Up T-Max } \\
\text { (manufacturer: Orkla, ingredients: wheat flour, } \\
\text { antioxidant E300, enzymes: xylanase, lipase, } \\
\text { amylase, oxidase, cellulase, dextrose) }\end{array}$ & $\begin{array}{l}\text { kneading: } 10 \text { minutes on a single-speed mixer } \\
\text { (100 rpm) with fork-type mixing arm; } \\
\text { dough resting: } 20 \text { min; } \\
\text { partition: } 355-365 \mathrm{~g} \text {; } \\
\text { round moulding; } \\
\text { resting: } 5 \mathrm{~min} \text {; } \\
\text { long moulding; } \\
\text { fermentation: under controlled conditions: } 35 \\
\text { min at } 37^{\circ} \mathrm{C}, 78 \% \text { moisture; } \\
\text { baking: } 220^{\circ} \mathrm{C}, 20 \text { min. }\end{array}$ \\
\hline
\end{tabular}

The control flours moisture was characterized by values ranging from $13.95 \%$ for dark wheat flour to $14.9 \%$ for white wheat flour. The moisture of white quinoa flour was significantly higher than that of the red quinoa flour $(13.83 \%$ vs. $13.60 \%$, $\left.\mathrm{t}=3.491^{*} ; \mathrm{p}<0.05\right)$.

The protein content between wheat flours had significant different values. Thus, between dark and white wheat flour there was an extremely significant difference in the protein content of about $5.74 \%\left(\mathrm{t}=152.093^{* * *} ; \mathrm{p}<0.001\right)$. The two quinoa flours also differed in terms of protein content, which was extremely significant higher in red quinoa $(17.3 \%)$ than in white quinoa flour $(11.47 \%)\left(\mathrm{t}=66.105^{* * *}\right)$. Quinoa whole flours have a protein content similar to whole wheat flours (about $16 \%$ D.M.), but higher than those obtained from barley (11.0\% D.M.), rice (7.5\% D.M.) or corn (11.5\% D.M.) (Abugoch et al., 2008; Ando et al., 2002). Compared 
to other cereals, quinoa seeds are characterized by a higher content of lysine (amino acid considered limitative to most conventional cereals), methionine and histidine (James, 2009; Repo-Carrasco et al., 2003; Wright et al., 2002).

Table 3. Physical and chemical quality parameters of wheat flours and mixtures $(n=3)$

\begin{tabular}{ccccccc}
\hline $\begin{array}{c}\text { Parameter/ Flour } \\
\text { type }\end{array}$ & M, \% & $\mathbf{P , \%}$ & $\mathbf{A , \%}$ & WG, $\%$ & GI & FN, s \\
\hline Dark wheat flour & 13.950 & $17.567 \pm$ & $0.993 \pm$ & $42.400 \pm$ & $86.000 \pm$ & $421.667 \pm$ \\
(M1) & \pm 0.050 & 0.058 & 0.030 & 0.529 & 2.000 & 7.637 \\
Type 480 wheat & $14.900 \pm$ & $11.833 \pm$ & $0.480 \pm$ & 30.233 & $68.667 \pm$ & $412.000 \pm$ \\
flour (M2) & 0.264 & 0.058 & 0.010 & \pm 0.208 & 3.512 & 13.115 \\
White quinoa flour & $13.833 \pm$ & $11.466 \pm$ & 1.010 & & & \\
(WQ) & 0.058 & 0.115 & \pm 0.01 & ud & ud & $>1000$ \\
Red quinoa flour & 13.600 & $17.300 \pm$ & $3.370 \pm$ & & & \\
(RQ) & \pm 0.100 & 0.100 & 0.040 & ud & ud & $>1000$ \\
M1-15 WQ & $13.900 \pm$ & $17.233 \pm$ & $1.000 \pm$ & $37.500 \pm$ & $85.333 \pm$ & $564.333 \pm$ \\
& 0.100 & 0.153 & 0.010 & 0.300 & 0.577 & 14.361 \\
M1-30 WQ & $13.700 \pm$ & $16.267 \pm$ & $1.010 \pm$ & $30.933 \pm$ & $89.000 \pm$ & $838.333 \pm$ \\
& 0.100 & 0.252 & 0.010 & 0.551 & 1.000 & 5.033 \\
M1-15 RQ & $13.867 \pm$ & $17.733 \pm$ & $1.420 \pm$ & $35.667 \pm$ & $86.333 \pm$ & $500.667 \pm$ \\
& 0.058 & 0.058 & 0.030 & 0.321 & 1.527 & 10.066 \\
M1-30 RQ & $13.800 \pm$ & $17.633 \pm$ & $1.760 \pm$ & $31.600 \pm$ & $87.000 \pm$ & $557.667 \pm$ \\
& 0.100 & 0.115 & 0.040 & 0.300 & 1.000 & 9.849 \\
M2-15 WQ & $14.733 \pm$ & $12.233 \pm$ & $0.600 \pm$ & $26.267 \pm$ & $79.000 \pm$ & $440.000 \pm$ \\
& 0.058 & 0.153 & 0.020 & 0.416 & 3.605 & 12.490 \\
M2-30 WQ & $14.633 \pm$ & $12.100 \pm$ & $0.710 \pm$ & $21.300 \pm$ & $69.667 \pm$ & $552.667 \pm$ \\
& 0.058 & 0.100 & 0.030 & 0.300 & 4.509 & 8.737 \\
M2-15 RQ & $14.667 \pm$ & $12.400 \pm$ & $1.070 \pm$ & $26.467 \pm$ & $79.667 \pm$ & 400.667 \\
M2-30 RQ & 0.115 & 0.100 & 0.020 & 0.351 & 0.577 & \pm 12.503 \\
& $14.700 \pm$ & $12.700 \pm$ & $1.560 \pm$ & 21.300 & $70.333 \pm$ & $486.000 \pm$ \\
& 0.100 & 0.200 & 0.060 & \pm 0.100 & 1.527 & 15.100 \\
\hline
\end{tabular}

ud-undetermined

The mineral content (ash) differed significantly between the controls, but also between the two quinoa flours. Thus, the mineral content was extremely significant higher in red than white quinoa $(3.37 \%$ vs. $1.01 \%$; $t=99.140 * * *)$. Quinoa flours, both white and red, had a significantly higher content of minerals than white flour. In terms of mineral content, quinoa flour can be considered an important source of phosphorus, potassium, magnesium and zinc. It is estimated that $100 \mathrm{~g}$ of quinoa seeds can cover the daily needs of magnesium, manganese, copper and iron for children and adults, respectively up to $40-60 \%$ of their daily phosphorus and zinc requirements (Konishi et al., 2004).

The control flours wet gluten was characterized by high values $(42.40 \%$ for dark flour and $30.23 \%$ for white flour), so they can be characterized as having superior 
bakery potential. The addition of quinoa flours resulted in a corresponding decrease in wet gluten content of the mixtures, at a rate dependent on the amount of added quinoa flour. The decrease was strong enough in the large additions of quinoa flours, when wet gluten fell to values incompatible with the bakery qualities (ex. in the case of white wheat flour, the addition of $30 \%$ quinoa flour, determined the decrease of wet gluten to $21.3 \%$ ). This effect underlines the importance of the wet gluten parameter in choosing wheat flour to be used in the making of quinoa added bakery products. It is preferable that the value of wheat flour gluten, to which quinoa flour is added, should be as high as possible.

The gluten index value was very significantly higher in dark wheat flour (86.000) than in white wheat flour $\left(68.667 ; \mathrm{t}=7.514^{* *} ; \mathrm{p}<0.01\right)$. The addition of quinoa flours to dark flour did not significantly alter the value of the gluten index, regardless of the quinoa flour type used for the tested variants (15 vs. 30\%) (t values of max. 2.169 is-insignificant). In the case of white wheat flour, characterized by a lower initial value of the gluten index, for both variants of $15 \%$ white or red quinoa flour addition, the results showed a significant increase in the gluten index. This increase was from 68.667 to 79.000 in the case of white quinoa addition $\left(\mathrm{t}=3.100^{*}\right)$ and to 79.667 for red quinoa addition $\left(\mathrm{t}=4.193^{*}\right)$. White wheat flours treatments with $30 \%$ quinoa flour did not significantly alter the gluten index value.

The wheat flours used as control did not differ significantly in terms of the falling number value ( $421.7 \mathrm{sec}$ for dark wheat flour, respectively $412 \mathrm{~s}$ for white wheat flour; $\mathrm{t}=1.103$ is). On the other hand, the values of this parameter for quinoa flours were very high, beyond the usual values of wheat flours (over $1000 \mathrm{sec}$ ). Thus, it can be said that quinoa flours quickly form more consistent and stable gels than wheat flours. The effect of quinoa flours addition differed, depending on the type of wheat flour and depending on the type of quinoa flour.

Thus, in the case of dark wheat flour, the addition of quinoa flours results in significant increases in the falling number parameters, corresponding to the used quantities. The increasing effect was more pronounced in the case of white quinoa whole flour addition (increase of $+416.6 \mathrm{sec}$ compared to the control, in $30 \%$ variant), compared to the red quinoa whole flour addition (increase of $+136 \mathrm{sec}$ compared to the control, in $30 \%$ variant). It is possible that the differences between the two quinoa flours are due to the higher fibers, protein and mineral content of the red quinoa flour, a composition profile that corresponds to a lower starch content, compared to white quinoa flour. Thus, it would also be a lower gelling ability of red quinoa flour.

In the case of white wheat flour, the addition of $15 \%$ quinoa flour did not significantly change the value of the falling number (from $412.0 \mathrm{sec}$. to $440.0 \mathrm{sec}$. in the case of white quinoa flour addition $\mathrm{t}=2.678$, respectively at $400.7 \mathrm{sec}$. in case of red quinoa flour addition $t=1.080 \mathrm{in}$ ). The addition of $30 \%$ quinoa flour has led to a significant increase in the value of the falling number to $552.7 \mathrm{sec}$ (WQ), respectively $486.0 \mathrm{sec}$. (RQ). It was also noted that the addition of white quinoa flour had a more intense increasing effect than that of red quinoa flour. 
The farinograph analysis results of wheat flours and of mixtures with quinoa flours are presented in table 4 .

Table 4. Farinograph analyzes for wheat flours and mixtures

\begin{tabular}{|c|c|c|c|c|c|}
\hline $\begin{array}{l}\text { Parameter/ } \\
\text { Flour type }\end{array}$ & $\begin{array}{c}\text { Water } \\
\text { absorption } \\
(\%)\end{array}$ & $\begin{array}{l}\text { Development } \\
\text { time (min) }\end{array}$ & $\begin{array}{l}\text { Stability } \\
\text { (min) }\end{array}$ & $\begin{array}{c}\text { Dough } \\
\text { softening } \\
(10 \mathrm{~min} \\
\text { UF) }\end{array}$ & $\begin{array}{c}\text { Dough } \\
\text { softening } \\
(12 \mathrm{~min} \\
\text { UF) }\end{array}$ \\
\hline $\begin{array}{c}\text { Dark wheat flour } \\
\text { (M1) }\end{array}$ & $\begin{array}{c}65.633 \pm \\
0.252\end{array}$ & $\begin{array}{c}7.267 \pm \\
0.305\end{array}$ & $\begin{array}{c}11.867 \pm \\
0.153\end{array}$ & $\begin{array}{c}18.333 \pm \\
3.512\end{array}$ & $\begin{array}{c}55.667 \pm \\
4.041\end{array}$ \\
\hline $\begin{array}{l}\text { Type } 480 \text { Wheat } \\
\text { flour (M2) }\end{array}$ & $\begin{array}{c}56.100 \pm \\
0.300\end{array}$ & $\begin{array}{c}2.267 \pm \\
0.305\end{array}$ & $\begin{array}{c}12.067 \pm \\
0.513\end{array}$ & $\begin{array}{c}20.667 \pm \\
1.155\end{array}$ & $\begin{array}{c}31.000 \pm \\
3.605\end{array}$ \\
\hline $\begin{array}{l}\text { White quinoa flour } \\
\text { (WQ) }\end{array}$ & ud & ud & ud & ud & ud \\
\hline $\begin{array}{l}\text { Red quinoa flour } \\
\text { (RQ) }\end{array}$ & ud & ud & ud & ud & ud \\
\hline M1-15 WQ & $\begin{array}{c}68.133 \pm \\
0.231\end{array}$ & $\begin{array}{c}6.700 \pm \\
0.264\end{array}$ & $\begin{array}{c}5.833 \pm \\
0.115\end{array}$ & $\begin{array}{c}27.000 \pm \\
6.245\end{array}$ & $\begin{array}{c}72.667 \pm \\
4.726\end{array}$ \\
\hline M1-30 WQ & $\begin{array}{c}66.933 \pm \\
0.651\end{array}$ & $\begin{array}{l}6.533 \pm \\
0.153\end{array}$ & $\begin{array}{c}3.500 \pm \\
0.115\end{array}$ & $\begin{array}{c}45.000 \pm \\
5.000\end{array}$ & $\begin{array}{l}93.333 \pm \\
5.132\end{array}$ \\
\hline M1-15 RQ & $\begin{array}{c}66.300 \pm \\
0.300\end{array}$ & $\begin{array}{c}8.967 \pm \\
0.115\end{array}$ & $\begin{array}{c}8.833 \pm \\
0.378\end{array}$ & $\begin{array}{c}6.667 \pm \\
2.887\end{array}$ & 0 \\
\hline M1-30 RQ & $\begin{array}{c}65.633 \pm \\
0.252\end{array}$ & $\begin{array}{c}7.633 \pm \\
0.153\end{array}$ & $\begin{array}{c}4.067 \pm \\
0.451\end{array}$ & $\begin{array}{c}33.667 \pm \\
5.507\end{array}$ & $\begin{array}{c}79.000 \pm \\
3.606\end{array}$ \\
\hline M2-15 WQ & $\begin{array}{c}56.767 \pm \\
0.252\end{array}$ & $\begin{array}{c}4.667 \pm \\
0.115\end{array}$ & $\begin{array}{c}8.133 \pm \\
0.416\end{array}$ & $\begin{array}{c}28.667 \pm \\
1.155\end{array}$ & $\begin{array}{c}46.667 \pm \\
2.887\end{array}$ \\
\hline M2-30 WQ & $\begin{array}{c}59.433 \pm \\
0.404\end{array}$ & $\begin{array}{c}2.300 \pm \\
0.100\end{array}$ & $\begin{array}{c}4.200 \pm \\
0.529\end{array}$ & $\begin{array}{c}78.333 \pm \\
10.408\end{array}$ & $\begin{array}{c}99.333 \pm \\
4.509\end{array}$ \\
\hline M2-15 RQ & $\begin{array}{c}57.400 \pm \\
0.264\end{array}$ & $\begin{array}{c}1.767 \pm \\
0.252\end{array}$ & $\begin{array}{c}5.267 \pm \\
0.252\end{array}$ & $\begin{array}{c}73.333 \pm \\
2.887\end{array}$ & $\begin{array}{c}87.333 \pm \\
2.516\end{array}$ \\
\hline M2-30 RQ & $\begin{array}{c}57.467 \pm \\
0.153\end{array}$ & $\begin{array}{c}5.967 \pm \\
0.503\end{array}$ & $\begin{array}{c}6.000 \pm \\
0.200\end{array}$ & $\begin{array}{l}38.000 \pm \\
2.000\end{array}$ & $\begin{array}{c}97.333 \pm \\
6.429\end{array}$ \\
\hline
\end{tabular}

ud - undetermined; *significant, $\mathrm{p}<0.05 ; * *$ very significant, $\mathrm{p}<0.01 ; * * *$ extremely significant, $\mathrm{p}<0.001$

The water absorption of the two control flours was significantly different, being higher in the case of dark wheat flour compared to white wheat flour $(65.6 \%$ vs. $56.1 \%)$. The only conclusion that could be drawn from the analysis was that the addition of quinoa flours did not worsen this parameter.

The effect of these additions was dependent on the type of wheat flour and of quinoa flour. E.g. the addition of $15 \%$ white quinoa flour to dark wheat flour resulted in an extremely significant increase of the water absorption, from $65.6 \%$ to $68.1 \%$ ( $\mathrm{t}=12.166^{* * *}, \mathrm{p}<0.001$ ), while $30 \%$ white quinoa flour addition caused only a significant increase (from $65.6 \%$ to $66.9 \%, \mathrm{p}<0.05$ ). The addition of $15 \%$ white quinoa flour to white wheat flour significantly changed the dough water absorption (from 56.1 to $56.8 ; \mathrm{t}=0.949^{*}$ ), while the addition of $30 \%$ white quinoa flour led to an extremely significant increase (to $59.433 ; \mathrm{t}=11.473 * * *$ ).

The effect of red quinoa flour addition on the water absorption of the two wheat flours was less intense than in the case of white quinoa flour addition. Thus, in the 
case of dark wheat flour, the addition of $15 \%$ red quinoa flour caused only a slight increase in the water absorption (from $65.6 \%$ to $66.3 \%$ ), while the addition of $30 \%$ did not cause a significant change compared to control flour. In the case of white wheat flour, the addition of red quinoa flour had the same effect on the water absorption, regardless of the dose used (15 or $30 \%)$, namely: a very significant increase from $56.1 \%$ to $57.4 \%\left(\mathrm{t}=5.634^{* *}, \mathrm{p}<0.01\right)$. The way in which the addition of the two quinoa flours has changed the water absorption influenced the value evolution of the other farinograph parameters. Thus, although the dough development time of the control flours (wheat flours) were extremely different: 7.3 minutes for dark flour, respectively 2.3 minutes for white flour, the effect of the quinoa flour addition on the development time was not homogeneous. Where the addition of quinoa flours led to small changes in the absolute value of the water absorption (between 0 and $+1.37 \%$ ) compared to the control flour (M1-15 RQ, M130 RQ, M2-15 WQ, M2- 30 RQ) the dough development times increased (between 0.37 and $2.4 \mathrm{~min}$ ). In this case, we can see the increasing effect of the time required to incorporate quinoa flour components (fibers, proteins, mineral substances) into the dough. Where the addition of quinoa flour has led to large changes in the absolute value of the water absorption (between 1.3 and $+3.33 \%$ ) compared to the control flour (M1-15 WQ, M1-30 WQ, M2-30 WQ, M2-15 RQ), the dough development times decreased or were very close to those of the control (between 0.03 and $0.734 \mathrm{~min}$ ). In this case, the higher quantity of water initially available led to a faster hydration of the components of wheat flour compared to quinoa flour and to a faster reaching of the viscosity of $500 \mathrm{FU}$.

\section{Characterization of the dough samples}

The addition of quinoa flours to wheat flours caused a decrease in dough stability. We mentioned the high values of the two control flours dough stability (11.9 min. for dark wheat flour, respectively $12.1 \mathrm{~min}$. for white wheat flour). As a general feature, the effect on the dough stability decreasing was more intense in the case of white quinoa flour addition and less intense in the case of red quinoa flour addition.

The addition of quinoa flour determined the increase of dough softening, compared to its values in the control flours. The parameter increase was higher in the case of white quinoa flour addition, compared to red quinoa flour.

The results of the alveograph analysis of wheat flours and of the mixtures with Quinoa flours are presented in table $5(\mathrm{n}=3)$.

It is observed that the dark wheat flour was characterized by a very high value of extensibility $(185.3 \mathrm{~mm})$ and a low value of resistance $(46.7 \mathrm{~mm} . \mathrm{P} / \mathrm{L}=0.25)$. White wheat flour had a balanced resistance/extensibility ratio, the two values being moderate. The addition of quinoa flours resulted in a significant decrease of dough extensibility and a corresponding increase of resistance. The magnitude of these changes was determined by the initial values of the two parameters in the control flours. White quinoa flour had a lower effect of decreasing the dough extensibility, in mixtures with wheat flours, compared to red quinoa flour. Instead, red quinoa flour had a lower effect of increasing the doughs resistance, compared to white quinoa flour, in mixtures with wheat flours. 
Table 5. Alveograph analyzes for wheat flours and mixtures

\begin{tabular}{|c|c|c|c|c|c|}
\hline $\begin{array}{l}\text { Parameter/ } \\
\text { flour type }\end{array}$ & $\begin{array}{l}\text { Resistance } \\
\text { P (mm) }\end{array}$ & $\begin{array}{c}\text { Extensibility } \\
\text { L (mm) }\end{array}$ & $\begin{array}{c}\text { Mechanical } \\
\text { work, } \\
\text { W }\left(10^{-4}\right. \\
\text { J/g) }\end{array}$ & P/Lratio & $\begin{array}{c}\text { Elasticity } \\
\text { index } \\
\text { Ie }(\%)\end{array}$ \\
\hline $\begin{array}{l}\text { Dark wheat flour } \\
\text { (M1) }\end{array}$ & $\begin{array}{c}46.667 \pm \\
2.082\end{array}$ & $\begin{array}{c}185.333 \pm \\
10.016\end{array}$ & $\begin{array}{c}155.00 \pm \\
5.000\end{array}$ & $\begin{array}{c}0.252 \pm \\
0.050\end{array}$ & $\begin{array}{c}41.600 \pm \\
0.200\end{array}$ \\
\hline $\begin{array}{l}\text { Type } 480 \text { Wheat } \\
\text { flour (M2) }\end{array}$ & $\begin{array}{c}83.667 \pm \\
3.605\end{array}$ & $\begin{array}{c}88.667 \pm \\
2.309\end{array}$ & $\begin{array}{c}222.667 \pm \\
4.619\end{array}$ & $\begin{array}{c}0.944 \pm \\
0.006\end{array}$ & $\begin{array}{c}49.600 \pm \\
0.259\end{array}$ \\
\hline $\begin{array}{l}\text { White quinoa } \\
\text { flour (WQ) }\end{array}$ & ud & ud & ud & ud & ud \\
\hline $\begin{array}{l}\text { Red quinoa flour } \\
\text { (RQ) }\end{array}$ & ud & ud & ud & ud & ud \\
\hline M1-15 WQ & $\begin{array}{c}94.000 \pm \\
3.605\end{array}$ & $\begin{array}{c}102.667 \pm \\
3.786\end{array}$ & $\begin{array}{c}270.333 \pm \\
6.028\end{array}$ & $\begin{array}{c}0.916 \pm \\
0.065\end{array}$ & $\begin{array}{c}49.533 \pm \\
0.252\end{array}$ \\
\hline M1-30 WQ & $\begin{array}{c}125.333 \pm \\
5.033\end{array}$ & $\begin{array}{c}52.667 \pm \\
2.515\end{array}$ & $\begin{array}{c}241.333 \pm \\
3.214\end{array}$ & $\begin{array}{c}2.380 \pm \\
0.020\end{array}$ & $\begin{array}{c}47.232 \pm \\
0.681\end{array}$ \\
\hline M1-15RQ & $\begin{array}{c}80.667 \pm \\
2.082\end{array}$ & $\begin{array}{c}74.667 \pm \\
4.163\end{array}$ & $\begin{array}{c}188.333 \pm \\
10.408\end{array}$ & $\begin{array}{c}1.080 \pm \\
0.020\end{array}$ & $\begin{array}{c}47.200 \pm \\
2.820\end{array}$ \\
\hline M1-30 RQ & $\begin{array}{c}93.000 \pm \\
2.646\end{array}$ & $\begin{array}{c}36.333 \pm \\
0.577\end{array}$ & $\begin{array}{c}134.333 \pm \\
4.041\end{array}$ & $\begin{array}{c}2.560 \pm \\
0.040\end{array}$ & 0 \\
\hline M2-15 WQ & $\begin{array}{c}79.000 \pm \\
3.605\end{array}$ & $\begin{array}{c}36.000 \pm \\
4.000\end{array}$ & $\begin{array}{c}113.000 \pm \\
2.646\end{array}$ & $\begin{array}{c}2.194 \pm \\
0.004\end{array}$ & 0 \\
\hline M2-30 WQ & $\begin{array}{c}95.667 \pm \\
4.041\end{array}$ & $\begin{array}{c}24.333 \pm \\
1.527\end{array}$ & $\begin{array}{c}95.667 \pm \\
5.131\end{array}$ & $\begin{array}{c}3.932 \pm \\
0.006\end{array}$ & 0 \\
\hline M2-15 RQ & $\begin{array}{c}61.333 \pm \\
3.055\end{array}$ & $\begin{array}{c}42.667 \pm \\
2.082\end{array}$ & $\begin{array}{c}95.667 \pm \\
2.082\end{array}$ & $\begin{array}{c}1.437 \pm \\
0.002\end{array}$ & $\begin{array}{c}37.800 \pm \\
2.200\end{array}$ \\
\hline M2-30 RQ & $\begin{array}{c}81.000 \pm \\
3.605\end{array}$ & $\begin{array}{c}24.000 \pm \\
1.000\end{array}$ & $\begin{array}{c}82.000 \pm \\
2.000\end{array}$ & $\begin{array}{c}3.375 \pm \\
0.005\end{array}$ & 0 \\
\hline
\end{tabular}

As a rule, the addition of $30 \%$ quinoa flour has worsened the quality parameters, to the limit of bakery potential. Dark wheat flour, characterized by a very high value of extensibility, had a better rheological behavior, being able to take a larger quantity of quinoa flour by keeping its alveograph parameters at reasonable values.

The effect of quinoa flours addition on the alveograph mechanical work (W) was significantly influenced by the value of the control flours $\mathrm{P} / \mathrm{L}$ ratio. Although the value of alveograph mechanical work was higher in white wheat flour compared to dark flour $\left(222.7 \times 10^{-4} \mathrm{~J} / \mathrm{g}\right.$ compared to $\left.155 \times 10^{-4} \mathrm{~J} / \mathrm{g}\right)$, dark flour was the only one that registered significant increases in this parameter when adding quinoa flour. The increase of dark flour alveograph mechanical work, when adding quinoa flour, was due to dough ability to form extensible gluten networks, able to properly integrate quinoa flour components. Another explanation may start from the modification of dough water dynamics, knowing that quinoa flours have different water absorptions, compared to wheat flours and alveograph analysis takes place under constant hydration conditions. Thus, the addition of quinoa flours can lead to the formation of more consistent dough, from rheological point of view.

White quinoa flour had a spectacular effect of increasing the mechanical work, relative to red quinoa flour (from $155 \times 10^{-4} \mathrm{~J} / \mathrm{g}$ to $270.3 \times 10^{-4} \mathrm{~J} / \mathrm{g}$ at $15 \%$ addition, respectively to $241.3 \times 10^{-4} \mathrm{~J} / \mathrm{g}$ at $30 \%$ addition). Comparative, the results obtained 
for red quinoa flour addition were lower (increase at $188.3 \times 10^{-4} \mathrm{~J} / \mathrm{g}$ at $15 \%$ addition, respectively decrease at $134.3 \times 10^{-4} \mathrm{~J} / \mathrm{g}$ at $30 \%$ addition). Red quinoa flour had a higher fibers content than the white one. The fibers exerted probably a mechanical effect of breaking dough gluten films and by default, of reducing their ability to absorb mechanical stress.

In the case of white wheat flour, the addition of quinoa flours had a significant effect of reducing the mechanical work parameter. As shown above, although the white wheat flour mechanical work was higher, because of a small initial extensibility, the ability to preserve or increase the mechanical work absorbed by the dough when adding quinoa flours was extremely low. The effects of the two types of quinoa flours addition to dough were similar and brought the value of the mechanical work below the lower limit of bakery potential $\left(150 \times 10^{-4} \mathrm{~J} / \mathrm{g}\right)$. In the case of white quinoa flour addition the decrease effect was slightly lower than that observed for red quinoa flour addition.

Generally, it is seen that the addition of larger quantities of quinoa flours (30\%) resulted in the loss of dough elasticity (Ie \% decrease).

\section{Characterization of the bread samples}

Quinoa flour bakery properties are estimated to be very low compared to wheat flour or other cereals flours containing gluten. Most researches have been directed to obtain products such as: pasta, extruded snacks, gluten-free products (Gallagher et al., 2004; Doğan and Karwe, 2003; Caperuto et al., 2000). Most studies on production of quinoa flour bread aimed at obtaining gluten-free bakery products. In this type of products, the quinoa flour can reach up to $50 \%$, the results being considered positive with respect to other pseudo-cereals flours, due to the presence of natural emulsifiers in quinoa flour. However, the volumes obtained for these products are far from the minimum acceptability limits in the case of the Romanian consumer (about $1.4 \mathrm{ml} / \mathrm{g}$, compared to $4.5-5 \mathrm{ml} / \mathrm{g}$ in the usual bread) (AlvarezJubete et al., 2010).

Researches have been carried out to investigate the addition of red and white quinoa flour to superior white flour type to obtain bread. The results showed that the optimum quinoa flour amount, for an acceptable quality of the finished products, is in the range of $5-10 \%$, corresponding to bread volumes of 3.0-3.25 $\mathrm{ml} / \mathrm{g}$. The addition of $20 \%$ quinoa flour decreased the volume of bread below 2.5 $\mathrm{ml} / \mathrm{g}$ (Codina et al., 2016).

Flour mixtures were used to obtain bread (Figure 1). The results of the baking tests are presented in table 6 .

It can be observed that the addition of quinoa flours determined the increase of the technological water absorption, compared to the control flours water absorption. The increase in the water absorption was higher when adding red quinoa flour (about 1.5-4.0\%, depending on the used quantity) and quite modest when adding white quinoa flour $(0.4-3 \%$, depending on the amount, but also on the wheat flour type, the increase being more evident in the case of white wheat flour). 
Table 6. Results of technological analyzes and quality parameters of bread

\begin{tabular}{|c|c|c|c|c|c|}
\hline $\begin{array}{l}\text { Parameter/ } \\
\text { Flour type }\end{array}$ & $\begin{array}{c}\text { Technological } \\
\text { water } \\
\text { absorption (\%) }\end{array}$ & $\begin{array}{c}\text { Dough } \\
\text { temperature } \\
\left({ }^{0} \mathrm{C}\right)\end{array}$ & $\begin{array}{l}\text { Specific } \\
\text { volume } \\
(\mathrm{ml} / \mathrm{g})\end{array}$ & $\begin{array}{c}\text { Porosity } \\
\text { (\%) }\end{array}$ & $\begin{array}{c}\text { Core } \\
\text { moisture } \\
(\%)\end{array}$ \\
\hline $\begin{array}{l}\text { Dark wheat flour } \\
\text { (M1) }\end{array}$ & $\begin{array}{c}60.000 \pm \\
0.500\end{array}$ & $\begin{array}{c}26.400 \pm \\
0.100\end{array}$ & $\begin{array}{c}4.686 \pm \\
0.080\end{array}$ & $\begin{array}{c}79.050 \pm \\
1.767\end{array}$ & $\begin{array}{c}44.863 \pm \\
0.158\end{array}$ \\
\hline $\begin{array}{l}\text { Type } 480 \text { Wheat } \\
\text { flour (M2) }\end{array}$ & $\begin{array}{c}55.000 \pm \\
0.200\end{array}$ & $\begin{array}{c}26.400 \pm \\
0.115\end{array}$ & $\begin{array}{c}3.397 \pm \\
0.120\end{array}$ & $\begin{array}{c}80.910 \pm \\
0.650\end{array}$ & $\begin{array}{c}43.600 \pm \\
0.112\end{array}$ \\
\hline M1-15 WQ & $\begin{array}{c}60.500 \pm \\
0.158\end{array}$ & $\begin{array}{c}26.800 \pm \\
0.120\end{array}$ & $\begin{array}{c}3.803 \pm \\
0.084\end{array}$ & $\begin{array}{c}79.155 \pm \\
0.900\end{array}$ & $\begin{array}{c}44.440 \pm \\
0.158\end{array}$ \\
\hline M1-30 WQ & $\begin{array}{c}60.400 \pm \\
0.220\end{array}$ & $\begin{array}{c}26.400 \pm \\
0.150\end{array}$ & $\begin{array}{c}3.050 \pm \\
0.134\end{array}$ & $\begin{array}{c}72.450 \pm \\
0.390\end{array}$ & $\begin{array}{c}45.020 \pm \\
0.160\end{array}$ \\
\hline M1-15RQ & $\begin{array}{c}61.500 \pm \\
0.342\end{array}$ & $\begin{array}{c}26.600 \pm \\
0.100\end{array}$ & $\begin{array}{c}3.489 \pm \\
0.202\end{array}$ & $\begin{array}{c}78.010 \pm \\
1.390\end{array}$ & $\begin{array}{c}44.440 \pm \\
0.180\end{array}$ \\
\hline M1-30 RQ & $\begin{array}{c}64.000 \pm \\
0.750\end{array}$ & $\begin{array}{c}26.100 \pm \\
0.110\end{array}$ & $\begin{array}{c}3.096 \pm \\
0.062\end{array}$ & $\begin{array}{c}74.680 \pm \\
2.050\end{array}$ & $\begin{array}{c}44.510 \pm \\
0.120\end{array}$ \\
\hline M2-15 WQ & $\begin{array}{c}55.500 \pm \\
0.222\end{array}$ & $\begin{array}{c}25.400 \pm \\
0.110\end{array}$ & $\begin{array}{c}2.467 \pm \\
0.174\end{array}$ & $\begin{array}{c}74.819 \pm \\
1.085\end{array}$ & $\begin{array}{c}43.470 \pm \\
0.150\end{array}$ \\
\hline M2-30 WQ & $\begin{array}{c}58.000 \pm \\
0.350\end{array}$ & $\begin{array}{c}25.600 \pm \\
0.100\end{array}$ & $\begin{array}{c}2.104 \pm \\
0.051\end{array}$ & $\begin{array}{c}70.142 \pm \\
0.160\end{array}$ & $\begin{array}{c}44.460 \pm \\
0.100\end{array}$ \\
\hline M2-15 RQ & $\begin{array}{c}57.000 \pm \\
0.500\end{array}$ & $\begin{array}{c}25.200 \pm \\
0.115\end{array}$ & $\begin{array}{c}2.320 \pm \\
0.215\end{array}$ & $\begin{array}{c}75.097 \pm \\
0.347\end{array}$ & $\begin{array}{c}44.640 \pm \\
0.150\end{array}$ \\
\hline M2-30 RQ & $\begin{array}{c}59.000 \pm \\
0.250\end{array}$ & $\begin{array}{c}25.600 \pm \\
0.115\end{array}$ & $\begin{array}{c}2.106 \pm \\
0.055\end{array}$ & $\begin{array}{c}71.785 \pm \\
0.630\end{array}$ & $\begin{array}{c}44.790 \pm \\
0.118\end{array}$ \\
\hline
\end{tabular}

The addition of quinoa flour significantly reduced the volume of the bakery products, in relation to the volume of control breads, both for those made out of white wheat flour, as well as for those made out of dark flour. The bakery products obtained out of dark wheat flour had a higher volume than those made out of white wheat flour, which confirms the importance of the dough extensibility for the flours bakery potential. For additions up to $15 \%$ white quinoa flour, the breads had the highest specific volumes $(3.80 \mathrm{ml} / \mathrm{g}$ for dark wheat flour, respectively $2.46 \mathrm{ml} / \mathrm{g}$ for white wheat flour). For additions of $30 \%$ quinoa flours, the effects on the specific volume were similar, both for white quinoa as well as for red quinoa flour, regardless of the wheat flour type (white or dark).

The effect was similar in terms of the porosity parameter evolution. So, the porosity of quinoa flour products was significantly lower than the porosity of breads obtained exclusively from wheat flour. In the case of dark wheat flour, the addition of $15 \%$ quinoa flour allowed to obtain a porosity similar to those of the control flour. In the case of white wheat flour, porosity decreases from $80.9 \%$ to around $75 \%$, both for the addition of white or red quinoa flour. The addition of $30 \%$ quinoa flours significantly worsens the value of the porosity parameter, both for dark as well as for white wheat flour.

The breads moisture with quinoa flours addition did not vary dramatically compared to the moisture of the breads obtained exclusively from wheat flours. The highest moisture had the bread made out of dark wheat flour with $30 \%$ white quinoa flour addition (45.02\%). The largest moisture difference between the bread made from the control flour and the one with the addition of quinoa flour was 
observed in the white flour-30\% red quinoa variant $(+1.19 \%)$. For certain samples, the bread moisture obtained with quinoa flour addition was even lower than the moisture of bread obtained from the control flours. This phenomenon was observed in the following variants: dark wheat flour with $15 \%$ white quinoa flour $(-0.423 \%)$, dark wheat flour with 15 and $30 \%$ red quinoa flour $(-0.423 \%$, respectively $0.353 \%)$ and white wheat flour with $15 \%$ white quinoa flour $(-0.13 \%)$.
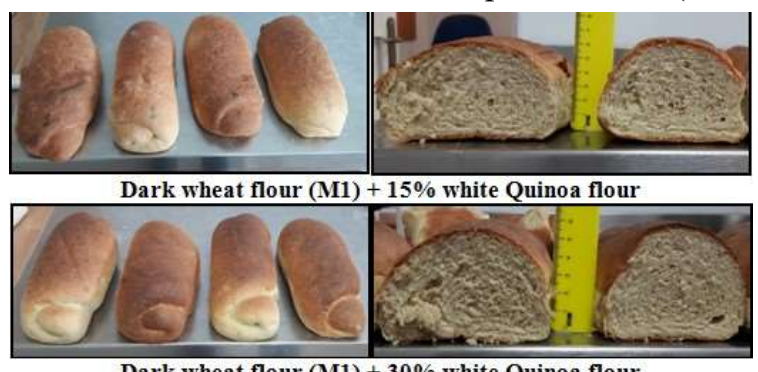

Dark wheat flour (M1) $+\mathbf{3 0} \%$ white Quinoa flour

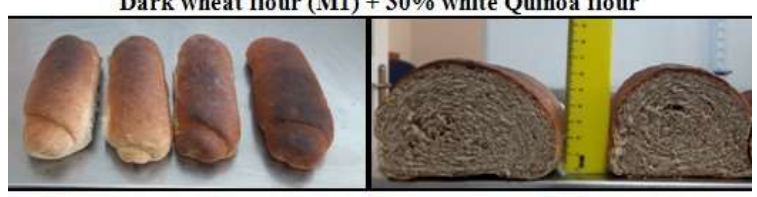

Dark wheat flour (M1) $+15 \%$ red Quinoa flour

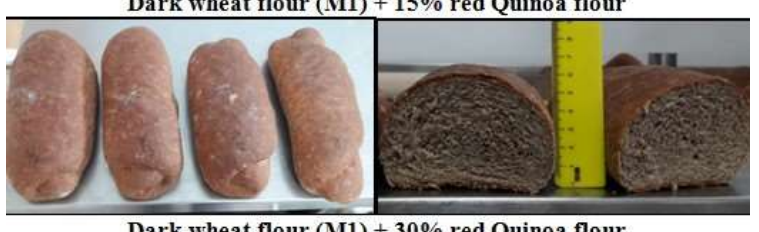

Dark wheat flour (M1) $+30 \%$ red Quinoa flour

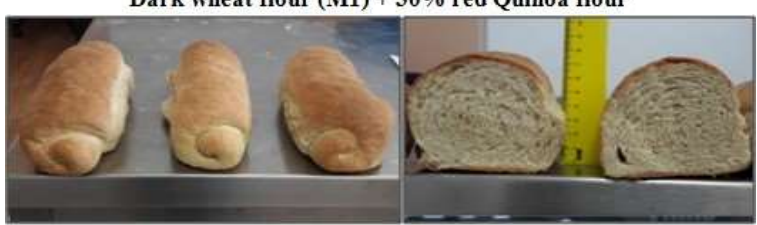

White wheat flour (M2) $+15 \%$ white Quinoa flour

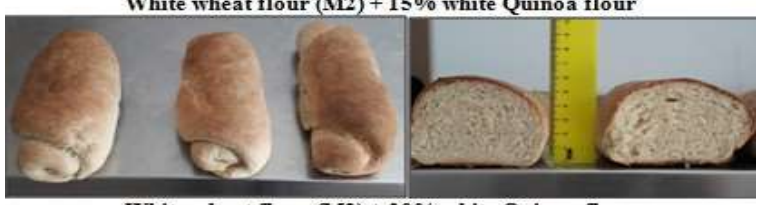

White wheat flour (M2) $+\mathbf{3 0} \%$ white Quinoa flour

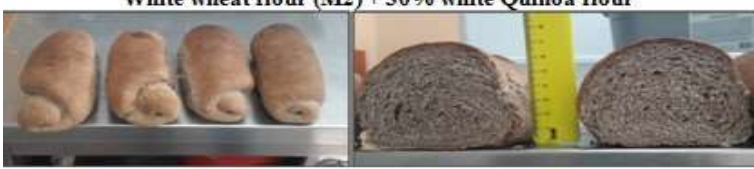

White wheat flour (M2) $+15 \%$ red Quinoa flour

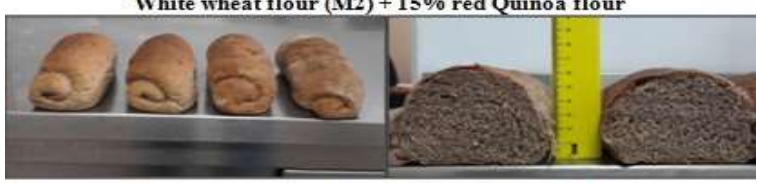

White wheat flour (M2) $+30 \%$ red Quinoa flour

Figure 1. General appearance and sections of breads with quinoa flours 
Figure 1 presents the general aspect and the section appearance of the finished products. The general appearance of the breads with the addition of red quinoa flour was similar to those obtained from whole wheat flour (reddish color of the crust, dark-colored core, medium porosity). The breads obtained with the addition of white quinoa flour had a light color, similar to the white wheat bread, commonly consumed on the Romanian market. Their crust was crispy, with a light-colored core section and a medium porosity.

Bread produced with quinoa flour addition to wheat flour, was obtained by Chauhan et al. (1992) using recipes having a quinoa flour content of up to $20 \%$. They appreciated that the optimal use of quinoa flour in making bread is max. $10 \%$. Park and Morita (2005) obtained bakery products using up to $10 \%$ quinoa flour from germinated seeds, finding that quinoa-wheat flours doughs are significantly improved by the addition of enzymes such as lipases. Kovács (2003) showed the favorable effect of transglutaminase on the quality of products obtained with quinoa flours. Salazar et al. (2017) concluded that the maximum utilization of quinoa flour added to wheat flour in bread recipes is $15 \%$, beyond this value the products being accompanied by a gradual loss of acceptability, due to the worsening of sensory attributes, like the appearance of a bitter taste.

\section{Conclusions}

The obtained results suggest that the optimum baking potential of wheat flours mixtures with quinoa flours was reached at a high value of extensibility and a low value of resistance.

Compared to white quinoa flour, red quinoa flour had worsened the values of mechanical alveographic work (probably due to its higher fibers content).

The addition of quinoa flours had the effect of increasing the technological water absorption of flour mixtures, especially with the addition of red quinoa mixed with white wheat flour.

The addition of quinoa flours significantly reduced the volume of breads compared to the control breads. The breads in mixtures with dark wheat flour had higher volumes than those with white wheat flours (the fact confirmed the importance of dough extensibility in realizing the flours baking potential). For additions up to $15 \%$ white quinoa the breads had the highest specific volumes $(3.8 \mathrm{ml} / \mathrm{g}$ for dark wheat flour and $2.5 \mathrm{ml} / \mathrm{g}$ for white wheat flour). For the additions of $30 \%$ quinoa flour, white or red, the effects on the bread volumes were similar, regardless of the type of wheat flour (white or dark).

The breads porosity with quinoa flours addition was significantly lower than the porosity of wheat flour products. In dark wheat flour bread, the addition of $15 \%$ quinoa flour has formed pores similar to those from bread obtained exclusively from wheat flour. In white flour bread, the porosity decreased from $80.9 \%$ to $75 \%$ both in addition of white or red quinoa flour. The addition of $30 \%$ quinoa flour, to dark or white flour, significantly worsened the bread porosity. 
The moisture content of flours mixtures did not significantly depend on the amount of quinoa flour added, but rather of specific technological conditions, like the amount of water used in doughs preparation (technological water absorption), which determined $58.3 \%$ of the breads moisture.

\section{References}

Abeywardena, M.Y., McLennan, P.L., Charnock, J.S. 1991. Differential effects of dietary fish oil on myocardial prostaglandin I2 and thromboxane A2 production. American Journal of Physiology-Heart and Circulatory Physiology, 260(2), H379-H385.

Abugoch, L.E., Romero, N., Tapia, C.A., Silva, J., Rivera, M. 2008. Study of some physicochemical and functional properties of quinoa (Chenopodium quinoa Willd) protein isolates. Journal of Agricultural and Food chemistry, 56(12), 4745-4750.

Aluko, R.E., Monu, E. 2003. Functional and bioactive properties of quinoa seed protein hydrolysates. Journal of Food Science, 68(4), 1254-1258.

Alvarez-Jubete, L., Auty, M., Arendt, E.K., Gallagher, E. 2010. Baking properties and microstructure of pseudocereal flours in gluten-free bread formulations. European Food Research and Technology, 230(3), 437.

Ando, H., Chen, Y.C., Tang, H., Shimizu, M., Watanabe, K., Mitsunaga, T. 2002. Food components in fractions of quinoa seed. Food Science and Technology Research, 8(1), 80-84

Berger, A., Jones, P.J., Abumweis, S.S. 2004. Plant sterols: factors affecting their efficacy and safety as functional food ingredients. Lipids in Health and Disease, 3(1), 5.

Berti, C., Ballabio, C., Restani, P., Porrini, M., Bonomi, F., Iametti, S. 2004. Immunochemical and molecular properties of proteins in Chenopodium quinoa. Cereal chemistry, 81(2), 275-277.

Caperuto, L.C., Amaya-Farfan, J., Camargo, C.R.O. 2001. Performance of quinoa (Chenopodium quinoa Willd) flour in the manufacture of gluten-free spaghetti. Journal of the Science of Food and Agriculture, 81(1), 95-101.

Chauhan, G.S., Eskin, N.A.M., Tkachuk, R. 1992. Nutrients and antinutrients in quinoa seed. Cereal Chem, 69(1), 85-88.

Chauhan, G.S., Zillman, R.R., Eskin, N.M. 1992. Dough mixing and breadmaking properties of quinoa-wheat flour blends. International journal of food science \& technology, 27(6), 701-705.

Codină, G.G., Franciuc, S.G., Todosi-Sănduleac, E. 2016. Studies on the influence of quinoa flour addition on bread quality, Food and Environment Safety, XV(2), 165- 174.

Doğan, H., Karwe, M. V. 2003. Physicochemical properties of quinoa extrudates. Revista de Agaroquimica y Tecnologia de Alimentos, 9(2), 101-114.

Gallagher, E., Gormley, T.R., Arendt, E.K. 2004. Recent advances in the formulation of gluten-free cereal-based products. Trends in Food Science \& Technology, 15(3), 143152.

James, L.E.A. 2009. Quinoa (Chenopodium quinoa Willd.): composition, chemistry, nutritional, and functional properties. Advances in food and nutrition research, 58, 1-31.

Jancurová, M., Minarovicová, L., Dandar, A. 2009. Quinoa-a review. Czech Journal of Food Sciences, 27(2), 71-79. 
Konishi, Y., Hirano, S., Tsuboi, H., Wada, M. 2004. Distribution of minerals in quinoa (Chenopodium quinoa Willd.) seeds. Bioscience, biotechnology, and biochemistry, 68(1), 231-234.

Kovács, E.T. 2003. Use of transglutaminase for developing pasta structure in pseudocereals systems. 3rd International Symposium on Food Rheology and Structure, http://citeseerx.ist.psu.edu/viewdoc/download?doi=10.1.1.604.5161\&rep=rep1\&type $=$ p df

Koziol, M.J. 1993. Quinoa: a potential new oil crop. New crops. 328-336.Wiley, New York.

Moreau, R.A., Whitaker, B.D., Hicks, K.B. 2002. Phytosterols, phytostanols, and their conjugates in foods: structural diversity, quantitative analysis, and health-promoting uses. Progress in lipid research, 41(6), 457-500.

Mundigler, N. 1998. Isolation and determination of starch from amaranth (Amaranthus cruentus) and quinoa (Chenopodium quinoa). Starch-Stärke, 50(2-3), 67-69.

Ogungbenle, H.N. 2003. Nutritional evaluation and functional properties of quinoa (Chenopodium quinoa) flour. International Journal of Food Sciences and Nutrition, 54(2), 153-158.

Ogungbenle, H.N., Oshodi, A.A., Oladimeji, M.O. 2009. The proximate and effect of salt applications on some functional properties of quinoa (Chenopodium quinoa) flour. Pakistan J Nutr, 8(1), 49-52.

Oshodi, H.N., Ogungbenle, M.O., Oladimeji, A.A. 1999. Chemical composition, nutritionally valuable minerals and functional properties of benniseed (Sesamum radiatum), pearl millet (Pennisetum typhoides) and quinoa (Chenopodium quinoa) flours. International journal of food sciences and nutrition, 50(5), 325-331.

Park, S.H., Morita, N. 2005. Dough and breadmaking properties of wheat flour substituted by $10 \%$ with germinated quinoa flour. Revista de Agroquimica y Tecnologia de Alimentos, 11(6), 471-476.

Park, S.H., Maeda, T., Morita, N. 2005. Effect of whole quinoa flours and lipase on the chemical, rheological and breadmaking characteristics of wheat flour. Journal of Applied Glycoscience, 52(4), 337-343. -nu e in text

Ranhotra, G.S., Gelroth, J.A., Glaser, B.K., Lorenz, K.J., Johnson, D. L. 1993. Composition and protein nutritional quality of quinoa. Cereal Chemistry, 70, 303-303.

Repo-Carrasco, R., Espinoza, C., Jacobsen, S.E. 2003. Nutritional value and use of the Andean crops quinoa (Chenopodium quinoa) and kañiwa (Chenopodium pallidicaule). Food reviews international, 19(1-2), 179-189.

Ruales, J., Nair, B.M. 1992. Nutritional quality of the protein in quinoa (Chenopodium quinoa, Willd) seeds. Plant Foods for Human Nutrition (Formerly Qualitas Plantarum), 42(1), 1-11.

Ryan, E., Galvin, K., O’connor, T.P., Maguire, A.R., O’brien, N.M. 2007. Phytosterol, squalene, tocopherol content and fatty acid profile of selected seeds, grains, and legumes. Plant Foods for Human Nutrition, 62(3), 85-91.

Salazar, D.M., Naranjo, M., Pérez, L.V., Valencia, A.F., Acurio, L.P., Gallegos, L.M., Arancibia, M.Y. 2017. Development of newly enriched bread with quinoa flour and whey. In IOP Conference Series: Earth and Environmental Science 77(1), 012018, IOP Publishing. 
Su-Chuen, Ng, Anderson, A., Coker, J., Ondrus, M. 2007. Characterization of lipid oxidation products in quinoa (Chenopodium quinoa). Food Chemistry, 101(1), 185-192.

Takao, T., Watanabe, N., Yuhara, K., Itoh, S., Suda, S., Tsuruoka, Y., Konishi, Y. 2005. Hypocholesterolemic effect of protein isolated from quinoa (Chenopodium quinoa Willd.) seeds. Food science and technology research, 11(2), 161-167.

Valencia-Chamorro S.A. 2003. Quinoa. In: Caballero B.: Encyclopedia of Food Science and Nutrition. 8, 4895-4902, Academic Press, Amsterdam.

Wright, K.H., Pike, O.A., Fairbanks, D.J., Huber, C.S. 2002. Composition of Atriplex hortensis, sweet and bitter Chenopodium quinoa seeds. Journal of food science, 67(4), 1383-1385. 